\title{
Mainstreaming Homosexuality in Nollywood: The Efforts and the Challenges
}

\section{Adedayo Ladigbolu Abah}

Associate Professor, Dept. of Journalism \& Mass Communications, Washington and Lee University, Virginia, USA

\begin{abstract}
A critical analysis of the attempts by Nollywood, the melodramatic videofilm industry in Nigeria, to address and mainstream the notion of homosexuality in Nigeria and across the continent. Using the cultivation theory and the inter-group contact theory, the study explores the notion of mainstreaming of homosexuality by the very popular medium across Africa. How has this particular medium address the issue of homosexuality in society through characterization and plot? Since Nollywood is a highly didactic medium, what messages about homosexuality are being presented and how do these messages contribute to or erode from existing conceptions and misconceptions about homosexuality in Nigeria? Has the medium, in its portrayal of homosexuality, contributed to the moral panic on the issue or help deflect the moral panic? The analysis is done against the backdrop of the ongoing legal, social and political homophobic rhetoric currently engulfing Nigeria and other African nations. The focus of the study is the frequency of reference to homosexuality in the society, the characterization of homosexual persons in the video-films and the narratives of the homosexual person in relation to heterosexuals in the society. The videofilms examined are: Emotional Crack (2003); Men in Love (2010) and Mind Game (2010). The results indicate that while more plots and characterization is being done by Nollywood to make homosexuality salient to the society, the characterizations of homosexuality is unsympathetic at best and even dubious in certain circumstances. In the one instance where a strong and sympathetic characterization is employed, the plot is undermined to restore the mainstream socio-religious homophobic discourse.
\end{abstract}

\section{Key Words: Homosexuality, Nollywood, Nigeria}

\section{BACKGROUND}

The issue of homosexuality in Africa has recently morphed to become another story in Africa's exceptionally in homophobia. Similar to most modern societies, both developed and developing, Africa as a continent is grappling with individual versus community rights especially when and how they pertain to concerns about religion, morality and sexuality. Currently, several nations in Africa legally criminalized homosexual acts, and those who have not legally proscribe the practice frown deeply on homosexuality. In 
November 2011 the Nigerian Senate passed a bill that made it a crime carrying up to 14 years imprisonment for gays to marry and prison term of 10 years for anyone who witnesses or in any way participates in such union.

"The bill will expand Nigeria's already draconian punishments for consensual same-sex conduct and set a precedent that would threaten all Nigerians' rights to privacy, equality, free expression, association and to be free from discrimination," said Erwin van der Borght, the director of Amnesty International's Africa program.i The bill must be passed by Nigeria's House of Representatives and signed by President Goodluck Jonathan to become law. South Africa remains the only country in Africa where homosexuality is legal.

The hostility currently depicted in the news media about the legal and social environment for homosexuals in Nigeria and elsewhere on the continent is alarming. Beyond the deprivation of basic human rights that these hostilities portray, it is also shutting off opportunities to have conversations about valid socially desirable behaviors and socially undesirable behaviors. The tendency to lump homosexuality together with socially deviant and criminal acts such as pedophilia and bestiality does not allow real confrontation with real problems. Anglican Archbishop Nicholas Okoh of Nigeria told reporters at a July 14 [2010] press conference that "same-sex marriage, pedophilia and all sexual perversions should be roundly condemned" reports Mathew Davies (Episcopal News Service, July 15, 2010). It is worthy of note that Okoh succeeded Archbishop Akinola in March 2010 as the primate (Head) of Anglican Church Nigeria. Additionally, the continent's social and medical confrontation of HIV/AIDS has largely focused on heterosexual behavior. Consequently, health campaigns on preventive methods have not given adequate considerations to homosexual behavior. This ignorance may have great impacts on the efforts to control the spread of the disease on the continent.

\section{THEORIES}

Using cultivation theory (Gerbner, Gross, Morgan, Signorelli, \& Shanahan, 2002 as cited by Calzo and Ward, 2009) one can deduce that media exposure to homosexual representations may help cultivate viewers' attitude about homosexuality (Calzo and Ward, 2009). People are socialized into attitudes about sexuality and the agents of the socialization process include parents, peer, religion and media institutions (Ballard \& Morris, 1998, as cited by Calzo and Ward, 2009). Media portrayal may actually be more influential as a sex educator due to the controversial nature of the topic, which may dissuade discussion by peers and parents, and first-hand experience may also be highly limited (Calzo and Ward, 2009). Contact hypothesis is the "most often used theoretical framework for understanding approaches that emphasize attention to categories" as noted by the American Psychological Association (APA). "In this framework, people make sense of their social world by creating categories of the individuals around them, which includes separating the categories into in-group and out-groups." ii The more contact members of a majority have with the members of a minority group, the more likely they are to accept the minority group (Gordan Allport, 1954). Expanding on Allport's theory, Horton and Wahl (1956) came up with the notion that "one of the striking characteristics of the new mass media -radio, television and the movies, is that they give the illusion of face-to-face relationships with the performer" (251). Horton and Wahl called this 'face-to-face' relationship between performer and spectator a para-social relationship in their study Mass Communication and Para-social Interaction. Sabido (2004) distilled the 1960s study by Albert Bandura on media role-modeling in mass-mediated social learning theories and the 
Horton and Wahl's 1956 para-social learning theories. Sabido (2004) complemented the Bandura modeling studies and the Horton and Wahl (1956) para-social interaction to construct an understanding of the relationship between mediated messages and the consumer. He argued that media modeling is not just about cognitive understanding but also includes the emotive and affective domains of understanding. This para-social relationship between audience and media models is comparable to face-to-face interpersonal relationships. ${ }^{\text {iii }}$ Therefore, theoretically anyway, the more exposure an audience gets to members of a minority group even mediated contacts (para-social relationship), the more likely the audience is to feel like they have had contact with members of the minority good. If the mediated contacts are of positive nature, the audience may have positive associations with members of the minority group. Subsequently, one can theorize that: if Nollywood portrays homosexuals in its characterizations and storylines, and, in a positive way, the audiences of Nollywood might gradually come to feel a para-social relationship with homosexuals and this could lead to a less hostile environment for members of the group in Nigeria and elsewhere in Africa.

\section{Universal Human Rights and Africa}

The international standard for protecting rights for homosexuals is derived from the international language of basic rights of all individuals included in the United Nations' Universal Declaration of Human Rights (UDHR). The current international document for protecting universal human rights is UDHR which, when adopted in 1948 did not include language about homosexuality. However, if one accepts the later 1994 ruling by the UN's Human Rights Committee that the reference to "sex" as a protected status refers also to "sexual orientation" and concomitant practices, ${ }^{\text {iv }}$ then one can argue that the language incorporates homosexuality (this ruling, however, is by no means yet accepted universally as the normative interpretation of UDHR). The fact that Africans were not involved in the conversations leading to the adoption of the UDHR is common knowledge as most of what constitutes modern day Africa was still a territory of European nations when nations were adopting the tenets of the UDHR. Thus, there was no distinctive African perspective in the articulations of the theoretical assumptions for the universal human rights document. Regardless of this fact, "the struggle for independence in Africa predated the UDHR and remains, with the anti-apartheid campaign, the most popular and successful human rights movement known to African peoples" (Chidi Odinkalu, 2000:3). While the African Charter on Human and Peoples' Rights adopted in 1981 is symbolic of African universal assent to the international concerns about human rights, "neither the notion of justice that underlies human rights nor the experience of struggle to realize these rights is unknown to Africa." (Odinkalu, 2000:3). Schoalrs such as John Bewaji (2006), Oladele Balogun (2006), and Agbakoba, J and Nwauche, E.S. (2006) have researched the precolonial, indigenous African conceptualizations of human rights before contacts with Europeans and Arabs in Nigeria.

While many developed nations have been confronting human rights in relation to homosexuality for several decades, Africa's confrontation with the issue became international news in the last decade. And, as prevalent in news about Africa, the headlines of the international media coverage remains sensational and macabre. "Homosexuality in Africa Is Still Taboo" screams the National Public Radio (NPR) headline dated February 22, 2010 on its website (www.npr.org/templates/story/story.php?storyId=123973509). “Religion, Politics and 
Africa's Homophobia" reads the headline of a February 24, 2010 post on www.huffingtonpost.com On July 21, 2009, Megan Lindow of www.Time.com writes under the headline 'How homophobia fuels Africa's AIDS crisis." On May 29, 2010, The Economist reported on a "Well-locked Closet" where "[g]ays are under attack in poor countries-and not just because of local culture." While these are all true reports, nothing in the report is unique to Africa in the continent-wide attempts to grapple with modern day politics with its mixed elements of religion and moral stance on "family issues." Several countries in Africa and other places in the world have laws preventing homosexual sexual acts. Several of these nations inherited sodomy laws dating as far back as late $19^{\text {th }}$ century from British colonialism. Several of these countries are now coming to grips with existing and new laws made to address homosexuality and society. India recently (June 2009) overturned its 149-year old sodomy law.

Sexual rights, while not explicitly stated are articulated and implied in many idioms, proverbs and sayings of many cultures in Africa. Examples of such idioms from the Yorubas of southwest Nigeria include:

1. A o le so pe tori ki omo maku, ki omo ma fi epon baba e sere. A child is not allowed to turn his father's scrotum into a toy as way to prevent the child's death.

2. Oko nleri, obo nleri, ipade dori eni. The penis brags, the vagina brags but the sleeping mat will decide.

While these would be considered sexually explicit way of talking, it is also important to keep in mind that the facts of proverbs are so uncontroversial that they are actually used to explain non-sexual issues of life. Femi Osofisan (2008), a renowned African playwright, however, argued that while early African literature from Nigeria was very subdued about sexual matters, the new literature from Africa has become "promiscuously talkative" about the experience of love (2008:69). So much so that topics that were considered taboo in literature, such as prostitution, abortion, sodomy and pederasty, gay and lesbian love have all become subject of opulent exposition. Quoting Olajubu (1972), Osofisan further noted that:

[T]o the Yoruba, sex has a sacred function...[but] in spite of this however, physical exposure of the sexual organs in life and in art, especially in carvings, is allowed... Obvious references to sex in words, gestures, and songs are also permitted on special occasions. On doors and veranda posts of temples and palaces can be found carvings of women with pointed, oversized breasts, and men with oversized penises. In some cases, for example, on the doors of Ife Town Hall, carvings of men and women in the sex act are depicted.

He then argued that the early literature from colonial and post-colonial Nigeria were mute or at best, subdued about sexual matters, not as a result of cultural dictates, but as consequences of Christian and Islamic indoctrination. Emerging from oral traditions of pre-colonial traditional societies into written forms that were dictated and taught in schools run by religious institutions, early written media were restrained with prudish silences and customary reticence in their expression of sex or sexual act.

As noted by Brody and Potterat (2003), several anthropological reports have documented the long and diverse history of homosexuality in multifarious African cultures. ${ }^{\mathrm{V}}$ Based on their distillation of several anthropological, physiological and epidemiological literatures on the issue, the author concurs with Brody and Potterat (2003) that "it was not homosexuality which was imported to Africa by Europeans but, rather its intolerance." ${ }^{\prime v i}$ While marriage and procreation may have been universally prescribed in most African societies, heterosexual attraction was not. However marginal, bisexuality and homosexuality co-existed in ancient African societies. ${ }^{\text {vii }}$ Peter Tarchell, a campaigner for gay rights, noted that "the real import into Africa is not homosexuality but politicized homophobia"viii 
Homosexual activity in Nigeria is legally proscribed. According to a 2007 Pew Global report, $97 \%$ of Nigerians think that homosexuality should be rejected. ${ }^{\text {ix }}$ Sanctions for homosexual act can be as severe as up to 14 years imprisonment or death by stoning if the offender is a Muslim from a Sharia law state. ${ }^{x}$ More recently, legislation was proposed in Nigeria that would ban same-sex blessing or marriage ceremonies, penalize those involved in them, and outlaw efforts to promote same-sex activity of any kind and through any means, with penalties of 14 years imprisonment for participants in such marriage or civil union activities and up to 10 years imprisonments for witnesses or collaborators in such ceremonies. Homosexuality has been catapulted into the forefront of political and religious, and therefore, social consciousness of the Nigerian polity in the last decade by a series of events. The murmurings and grumblings against homosexuality in the country became overt homophobia in 2003. One of the events that transported homophobia into a national pastime and created moral panic was the opposition of the then Primate of the Anglican Church Nigeria, Archbishop Akinola, to the installation of the openly gay Gene Robinson as Bishop of New Hampshire by the Episcopal Church in America. The Nigerian Anglican Church is the largest single group in the world with over 17 million members, which is about 11 percent of the Nigerian population. The dissention of Akinola and other African Anglicans, and Anglicans all over the world who were opposed to the installation led to a schism in the Anglican Church worldwide. ${ }^{x i}$ The then president of Nigeria, Olusegun Obasanjo (a well known member of the Anglican Church) instigated a legislation that would prevent same-sex union in the country. Any existing tolerance or indifference to homosexuality was jettisoned at this point for a political position on the impending legislation.

Despite the severity of sanctions for homosexual acts in Nigeria, several individuals continue to live their lives as homosexuals in Nigeria both openly and covertly. Coming out of the closet still carries a real danger to life and limb, nevertheless, people continue to live their lives the best they can under the circumstances and there are now organizations that exist to protect homosexuals from public persecution.

In light of the negativity, fear, curiosity, misinformation and danger that conflate in the discussion of homosexuality in Nigeria, it is critical to examine the contributions that Nollywood, a very important avenue for story-telling in Nigeria and all over the continent, is engaging with the pervasiveness of homophobic rhetoric in the public space.

\section{NOLLYWOOd IN NigeRIA}

Many scholars have addressed the popularity of Nollywood among audiences in Africa and in the diaspora. Marston, Woodward and James (2007) noted that "...these video films, popular commercial creations produced largely in the informal sector, are enthusiastically received by a wide audience of Africans and others all over the continent as well as abroad." xii Jonathan Haynes (2008) makes a similar observation about the popularity of the video-films when he said:

They are what is on television in Namibia and on sale on the streets in Kenya. In Congo, they are broadcast with the soundtrack turned down while an interpreter tells the story in Lingala or other languages. In New York, their biggest consumers are now immigrants from the Caribbean and African Americans, not Africans, and Chinese people are buying them too. In Holland, Nollywood stars are recognized on the streets by people from

Suriname, and in London they are hailed by Jamaicans. xiii

While their commercial nature might make the video-films appear apolitical and "grounded in an unapologetic commercial culture and seem quite indifferent to the social 
responsibility agenda of contemporary cinema, [there are still]...several examples of popular entertainment media serving social responsibility functions" (Ukadike, 1994: 258). Adesokan (2009) noted that their "treatment of political themes reflects a basic concern with good governance and ethical conduct in civil matters, which is then assimilated to the ideological orientation of didacticism" (p. 617). Haynes (2006) concurred in the assertion that despite their melodramatic forms, the video films are political and exhibit social consciousness.

Jean-Francois Werner (2006) noted that Africans now spend an enormous amount of time watching television and alluded to the Senegalese method of watching television with their children in concluding that social effects of television programming includes the acculturation of children to how culture is defined, contested and reinforced. He further noted that the acculturation effects for children also include its introduction to both modern and traditional channels of social communication, which is used in the discussion of television programming.

This preoccupation with moral teaching is not deviant behavior for the video films. The use of popular media for social change has been noted in the works of several scholars. Arvind Singhal (2007) observed that popular entertainment media are the most popular genre of mass media programming and hold value for "stimulating public discourses on social issues at the local, national, or global level and especially on topics that are considered [taboo]: sexuality, HIV/AIDS prevention, mental depression, ethnic cleansing, racial discrimination, and the like" (p.259). While concerned with the question of whether the commercial viability of popular global media can be burdened by the weight of social responsibility, he remarked on several examples from all over the world in which popular entertainment media has been used for social and educational purposes. One of his examples is the Tinka Tinka Sukh (Happiness lies in small things) soap opera on All India Radio in New Delhi. In 1996, villagers from Lutsaan from the state of Uttar Pradesh mailed a poster with 184 signatures and thumbprints to the radio station to protest the practice of dowry because the show's protagonist committed suicide after suffering abuse from her groom for having inadequate dowry (Singhal, 2007:259). On a popular Brazilian telenovela, when Camilla, the protagonist on Lazos de Sangre (Blood Ties), was diagnosed with leukemia, the Brazilian National Registry of Bone Marrow Donors reported increase of 450 percent in new donor registrations from about 20 a month to about 900 a month. ${ }^{\text {iv }}$

Nollywood has demonstrated that in its own way, it is not shy about offering critiques on unjust cultural practices in its productions. For examples, the rites and rights of widows in some south eastern cultures in Nigeria in which widows are deprived of their husbands' wealth by the deceased's relatives, and are made to undergo several unpleasant rituals have been severally addressed by Nollywood (e.g. Widow, 2008). Other unusual cultural practices that are onerous on both men and women have also been addressed by the industry, for example, Iyawo Saraa, a Yoruba language video film dealing with a Yoruba sub-culture of fostering unwilling young women as wives on unwilling young men on the basis of tradition. Just like the print media in Nigeria and the Yoruba travelling theater, Nollywood social activism have been more vociferous on issues of good governance, corruption in government, health-prevention of and living with HIV / AIDS, and sustenance of social norms.

\section{NollywOOd AND HomoseXUALITY}

Homosexuality is a novel area and a somewhat taboo subject not just for Nollywood but for the Nigerian media in general. This is because, even in social settings, there is a visceral 
repulsion attached to broaching the subject and this repulsion is arguably fuelled by the fight for moral superiority between Pentecostal Christianity overwhelming southern Nigeria and the furious adoption of Sharia laws by Muslims in the North. The furious fight for the right to claim the higher moral ground could also be classified as a "response to the anxieties of contemporary West African life" (Singhal, 2007:259). There is no middle ground in these religious contestations because, to be a moderate is to be licentious and bring either Islam or Christianity to moral ridicule. The misunderstanding surrounding social debate about homosexuality is palpably polluted with ignorance and misinformation that opportunities for dialogue in the media as a public sphere is completely obliterated. Online gatherings are the only places where some sort of dialogue is taking place and even these, in the perennial combative nature of online discussions, are highly judgmental and polarized in nature with very little attempt at education or understanding. In 2007 as the legislative debates on a bill to forbid gay unions were ongoing, Tide Online, one of the Nigerian newspapers reported that "...about four per cent of Nigerians are involved in same sex relationship. As reported by the same newspaper, special adviser to the President, Prof Friday Okonofua, said (at a public hearing on a bill to prohibit same sex marriage and relationship, organized by the House of Representatives Committee on Women Affairs, in Abuja), "...such relationships, had exposed those engaged in it to high risk of contacting sexually transmitted diseases (STDs), HIV / AIDS and cancer." Same-sex relationships, he said, "caused mental retardation, depression and high tendency to commit suicide." (TideOnline, Feb. 22, 2007). It is worthy of note that Prof. Okonofua, the special adviser to the President who was giving this testimony is a well published Professor of obstetrics and gynecology at Univ. Benin, Benin City, Nigeria in the areas of maternal health.

Within this cultural and social context, Nollywood tentativeness toward the subject can be well understood. The first few Nollywood video films dealing with the subject mainly discussed female homoeroticism. The nature of the discourse of lesbianism in these video films has been adequately addressed by some scholars (Lindsay Simms, 2009; Unoma Azuah, 2008). It was recently that Nollywood became daring enough to directly address male homosexuality. Nollywood addresses the issue the same way it addresses all themes, tentatively at first, and suddenly, a glut of video films on the theme. After a spurt of movies on female homosexuality, male homoeroticism was tentatively addressed as a moneymaking occult ritual in a Yoruba movie called -Aaro Meta (2003). In End Times (2004), the theme was addressed in the context of God versus devil in which the protagonist, a pastor, gets all his power from the devil and while his life as a homosexual was glossed over, the sinful nature of the lifestyle was lumped with other ills of the Pastor, such as deceitfulness. Recently however, there have been several Nollywood videos addressing male homoeroticism in a direct way. Not just through insinuation but directly portraying intimacy and public display of affection between males. Such portrayals, despite the illegality of such relationship in the country, is, on the one hand, bringing saliency to homosexuality in the society, and at the same time, creating anxiety about the threat of homo eroticism to the modern heteronormative home.

Three current Nollywood videos in particular are examined for explicit portrayal of the homoerotic lifestyles as well as post modern articulation of the fear and anxieties of the homosexual lifestyle on the heteronormative family unit. The videos are Emotional crack (2003), Men in Love (2010) and Sexy/Mind Game (2010).

Emotional Crack tells the story of a post modern hetero normative family. Chudi was the husband and Crystal the wife. Chudi is an abusive and unfaithful husband who beats his wife on every slight provocation. He was authoritarian and rude to his wife and her family 
who repeatedly asked Crystal to leave him. Chudi was also seeing Camille, an independent woman who is characterized by short Rastafarian braids, excessive smoking and a brash attitude. When physically threatened by Chudi, she, unlike Crystal, stood up to Chudi and let him know she was not afraid of him. At the urgings of a pastor, Chudi decided to change his ways and be faithful to his wife. He also stopped the physical abuse. While the abuse was ongoing, Crytal met Camille and with no prior knowledge of Camille's relationship to Chudi, Crystal formed a friendship with Camille. The friendship quickly evolved into a sexual one. After Chudi met God and decided to change his ways, Crystal decided to end the sexual part of her relationship with Camille especially because Camille was asking her to leave Chudi and be monogamous with her. As Crystal sought to end the relationship, Camille sought for ways for Chudi to see them together being intimate. She succeeded and Chudi promptly threw Crystal out of the matrimonial home. While Crystal sought to put her marriage back, Camille sought to have Crystal back. The rejection from Crystal deranged Camille and she sets out on a mission to have Crystal or destroy her. She managed to get Crystal alone and went on an attack with a knife. Crystal was saved from the attack by Chudi and Camille stabbed herself to death.

In Men in Love, we have another post-modern heteronormative family with a young son and another child on the way. Whitney is married to Charles, a successful business man who was also a philanderer. Alex, a long-ago college friend came into their lives. Alex was attracted to Charles. When Charles repeatedly rebuffed Alex advances, Alex decided to drug his drink and rape him. After the rape, Charles became enamored of Alex and moved Alex into the matrimonial home. Alex took over the cooking and cleaning as well as other traditional wifely duties in the home because he was good at them and Whitney didn't mind.

http://www.youtube.com/watch?v=CT0ba9pshz8 (Video clip that shows the scene where Alex and Whitney fight over who has the right to cook for Charles).

Whitney, who was clueless about the nature of the real relationship between her husband and Alex, believed that Alex had a calming effect on her husband as Charles had stopped his philandering ways since he became reunited with Alex. Charles and Alex went around in public holding hands, touching and socializing as gays openly. Pregnant Whitney caught Charles and Alex making love and moved out of the home with her son. http:/ / www.youtube.com/watch?v=1NBcDTh29k4 (scene where Whitney walked in on Alex and Charles making love). Charles didn't care. Through some church intervention, Whitney discovered that her husband was under a mysterious spell cast on him by Alex. It was the spell that made Charles temporarily homosexual and uncaring toward the wife. Through the intervention of prayers, the spell was removed, Charles was reunited with his pregnant wife and son, and Alex was arrested for homosexual acts at the instigation of Whitney.

In the plot of Mind Games (2010), Betty who has been married to Richard for four months walked in on her husband being intimate with another man. This is after four months of her husband avoiding any intimacy with her. She is torn between leaving her husband and staying. Richard professes love for his wife but admitted to his wife and his mother that he had always known he was gay. http://www.youtube.com/watch?v=019xjury5WY (scene where Richard admitted to his family- wife, mother and wife's aunt that he was gay).

It is important to the plot that both Betty and Richard are born-again Christians. Richard makes a point that he cannot change who he was because he was born gay. Betty tried to convince him he didn't belong to the group of homosexuals anymore because of his bornagain status. Betty engaged on a mission of fasting and praying to save her husband from the clutches of homosexuality. In the meantime, Richard continues to receive texts and 
clandestine visits from his gay lover. The movie ended when Betty woke up and found that the whole experience was just a bad dream.

\section{Discussion}

It is noteworthy that most of Nollywood storytelling about homoeroticism is articulated in terms of its threat to the heteronormative family unit. While this represents the general and universal articulation of anxieties about the impact of homoeroticism on post modern society within Nollywood, it also feeds on the visceral homophobic discourses prevailing in the society, thereby creating a near moral panic about the threat of homoeroticism in modern families.

However, the daring way in which Nollywood is approaching the theme is also subtly subversive. While news reports note the difficulties of finding places for socialization for homosexuals in Nigeria, Men in Love unabashedly portrays gay men holding hands, touching and flirting openly in restaurants and places of public accommodation without consequences. To portray this in a country that criminalizes such socialization is remarkable. In both Emotional Crack and Men in Love, the homosexual characters were threats to the traditional family. In both video-films, the homosexual characters broke up the traditional home settings and it took divine intervention in both cases to reunite the families. In Emotional Crack, the lesbian character (Camille) was portrayed as deranged and had to kill herself in the end. It is also remarkable that she was essentially bi-sexual. She started out as a single lady having an illicit affair with a married man. She became interested in Crystal as a way to get back at the married man who dumped her after finding God and repenting of his cheating and abusive ways. The husbands in both Men in Love and Emotional Crack were either abusive or cheaters-and in the case of Emotional Crack, both- however, in both cases, abusive and cheating husbands were still preferable to homosexual partners. According to both videos, with divine help, abusive husbands can change, but homosexuals either commit suicide when the burden of their taboo desire becomes unbearable (as the Camille character in Emotional crack) or they go to jail after their supernatural hold on innocent victims have been divinely broken as in the case of Men in Love. In these story lines, love is rarely addressed as a possible motivation for homosexual liaisons and the rare occasions it was addressed in Emotional crack, it turned out it was a means of manipulation. However, love is presumed to be the glue for the heterosexual relationships. Even in abusive relationships such as the one in Emotional Crack where Crystal was being brutally abused physically and verbally by her husband and her family was begging her to leave him. She couldn't leave him because she loved him too much. Even after being hospitalized as a result of another vicious beating, Chudi was able to plead his way back into her heart. In the case of Men in Love, Charles cheats on his wife with other women but the video made sure the audience understood that he still loved her and she loved him despite their problems.

The homosexual characters on the other hand were never in the relationship for love. Camille was a chain-smoking, independent but predatory woman who wanted another man's wife. Her forage into homosexuality was an attempt to punish Chudi for tossing her aside. Her relationship with Camille had nothing to do with love but everything to do with anger and revenge. In the case of Alex and Charles, Alex was not in love with Charles but wanted Charles for the socio-economic benefit of being the sex toy of a rich man. He bragged to his friends about his access to expensive cars and a better lifestyle because of Charles. Charles was just his access key to a better lifestyle. As for Charles, he was not in love with Alex either, he was under a spell according to the video-film. Alex's character was 
manipulative, cunning and greedy. He was not a sympathetic character and neither was Camille. It is also important to know that Charles was married with children and all he wanted was to continue his sexual relations with Alex while remaining married to Whitney. He is essentially bi-sexual just like Camille in Emotional Crack.

Mind Game was the one attempt to use both plot and characterization to address homosexuality in a compassionate manner. The couple is a born-again Christian and yet, the man finds himself attracted to men. The torment and anguish of people who find themselves in a heterosexual liaison even when they know they are gay to satisfy society's demands were discussed. Richard professes his love for his wife Betty, but also proclaim that he cannot help his attraction to men because he was born gay. This addresses the notion that people make the 'bad' choice of being gay. This could have been a decent attempt to actually look at the notion of homosexuality through a very sympathetic characterization and also examine the perspectives of other family members when people come out of the closet-Richard's mother and Betty's aunt were involved in the conversations. The video presented all these possibilities but didn't follow through. The movie capitulated by making the whole thing a bad dream on the part of Betty. Richard couldn't consummate his marriage to his very beautiful wife because he is homosexual not bi-sexual. Omotola-Jolaade Ekehinde, one of the more acclaimed Nollywood actors played the part of Betty. Richard was obviously torn about his homosexuality and his desire to be 'normal' by societal standards. His homosexuality was not as a result of a spell or a means of revenge by a jilted lover. His internal conflict between the desire to be a 'normal' man and his desire for men was explored. He was a good man caught between being true to himself and doing what was expected of him.

While the issue of homosexuality has not been treated in any depth or even in a serious manner by the industry, it is still important that the industry continues to make video films addressing the issues. The earlier films on the issue were tentative, films like Aaro Meta, End Times and My Brother's Keeper were tentative in dealing with male homoeroticism. In these video-films, the details of the lifestyle were not included and it was always toward the end of the story that the viewer finds out that homoeroticism was being referenced. Female homoeroticism had not fared better as a theme in Nollywood. The women were almost always deranged, angry and violent. In the last few years however, male homoeroticism have taken center stage and more actors have become more willing to portray the physical act of male homoeroticism, and, bring the topic into the public sphere. It is not the industry's duty to resolve the issues for society, but, by portraying the lifestyle boldly, people can become familiar with seeing men with men and women with women, thereby, making it 'real' for some members of the audience. This may help in cultivating viewers' attitude toward homosexuality (Calzo and Ward, 2009). As argued by the contact hypothesis, the more contact members of a majority have with the members of a minority group, the more likely they are to accept the minority groups (Gordon Allport, 1954). Viewers who may never have met a homosexual person may also develop a para-social relationship comparable to a face-to-face relationship with a media character (Sabido, 2004; Horton and Wahl, 1956; Bandura, 1977) portraying the lifestyle, which might make them more compassionate in their treatment of homosexuality. Furthermore, if the mediated contacts are positive, the audience member may have positive vicarious associations with the minority group. However, when the portrayals are consistently negative, devious and lacking in depth, this may conversely create a negative sense of contact for people who have no opinion on homosexuality and affirm the homophobic discourses of audience members with existing homophobia by creating and perpetuating stereotypes. Also, in portraying 
homosexual characters as threats to heteronormative families, the industry may be deepening the fears and anxieties about the open expression of homoeroticism.

Characterization of homoeroticism that is multi-dimensional but sympathetic may be more effective in creating an opportunity for non-polarizing discussions of homoeroticism and modern society. Richard, the husband in Mind Games started out as one such character. He loves his wife, is a born-again Christian and was not malevolent in any way. His only 'failing' was his homosexuality. Such a character could have been developed to give an insight to the internal struggles and challenges faced by a gay man in modern day Nigeria. Rather, the movie got weak-kneed and sabotaged the issue by labeling it a bad dream on the part of the wife. The treatment of homosexuality in these videos is also not encouraging to many Nigerians and Africans watching and living in the closet. These portrayals offer neither relief nor understanding of the lifestyle. The video treatment of the issue could actually make it more difficult for anyone to come out of the closet because of the fear of losing friends, especially the married ones to whom you are now a threat according to the videos. Other than prayers and spiritual miracles, the videos offer no resource for having an open discussion about the issue.

Nevertheless, I think as Nollywood matures and gets bolder in its portrayals of the homoerotic lifestyle, it will evolve into educating its audiences about real issues such as health concerns, especially, with men who are married to women but are in homosexual relationships outside the marriage. Right now, health promotions and education about HIV/AIDS in Africa is centrally focused on heterosexual contacts with few, if any, concessions to homosexual relations. Making the issue salient will open the room for more relevant discussions about safe sex including safe homosexual sex and discussions about prevention and treatments will also be more nuanced.

Despite the current short-sightedness involved in the portrayal of homosexuality by Nollywood, it is still important to keep portraying the lifestyle in the hope of demystifying it for the general public. This summation is premised upon the assumption that when portrayal has moved beyond its current nascent stage, education and engagement with the issue might be the natural next steps in the industry. Currently, the stereotypical portrayal in Nollywood of the homosexual person as a threat to the traditional heterosexual home setting may be the first step in mainstreaming the lifestyle in the public consciousness. Strands of the conversation in video-films such as Mind Game could potentially allow the conversations about the lifestyle to evolve into saliency with the public and ultimately, acceptance.

\section{ENDNOTES}

${ }^{\mathrm{i}}$ http:/ / www.starobserver.com.au/news/2011/11/30/nigerian-senate-passes-anti-gay-bill/66899 (accessed 1/15/2012)

ii APA Council of Representatives. (2002). 'Guidelines on Multicultural Education, Training, Research, Practice, and Organizational Change for Psychologists." www.APA.org (accessed 10/07/2010).

iii Miguel Sabido, (2004). "The Origins of Entertainment-education." In Entertainment-education and Social Change: History, Research, and Practice, eds. A. Singhal, M. Cody, E.M. Rogers, and M. Sabido (Mahwah, NJ:Lawrence Erlbaum Associates Lawrence Erlbaum Associates). p.

iv The case, Toonen vs Australia, concerned the International Covenant on Civil and Political Rights (1996), Article 2.26 
${ }^{v}$ Stuart Brody and John J. Potterat. (2003). Assessing the role of anal intercourse in the epidemiology of AIDS in Africa. International Journal of STD EAIDS, 14 (7): 431-436. Available online at: www.cirp.ord/library/disease/HIV/brody2003/ (accessed on 10/05/2010).

${ }^{\text {vi }}$ Brody and Potterat (2003). www.cirp.ord/library/disease/HIV/brody2003/ (Accessed on 10/05/2010).

vii Brody and Potterat (2003). www.cirp.ord/library/disease/HIV/brody2003/ (Accessed on 10/05/2010).

viii The Economist, (5/29/2010). A well-locked closet. Available online at http://www.economist.com/node/16219402 (Accessed on 10/07/2010, subscription required).

${ }^{\text {ix }}$ http://pewglobal.org/files/pdf/258.pdf (Visited October 15, 2010).

$x$ http://www.awid.org/eng/Issues-and-Analysis/Library/Criminalizing-Homosexuality-theNigerian-Way (accessed October 15, 2010).

xi http://www.fulcrum-anglican.org.uk/news/2006/20061121radner.cfm?doc=167 (Visited October 21, 2010).

xii Sallie Marston, Keith Woodward and John Paul Jones, III. (2007). Flattening Ontologies of Globalization: The Nollywood Case. Globalizations, 4:1 p. 55.

xiii Jonathan Haynes. (2008). Nollywood: what's in a name?, Africine.org, 17 August 2008. Available at http:/ / www.africine.org/?menu=art\&no=8042 (visited October 10, 2010)

xiv T.V. Globo, The Camilla Effect (Sao Paulo, Brazil: TV Globo, 2003). As cited by Arvind Singhal (2007).

\section{REFERENCES}

Adesokan, A. (2009). Practising 'democracy' in Nigerian films. African Affairs, 108(433):599-619

Agbakoba, J and Nwauche, E.S. (2006). African Conceptions of Justice, Responsibility and Punishment. 37 Cambrian L. Rev. 73.

Allport, G. W. (1954). The nature of prejudice. Reading, MA: Addison-Wesley

Azuah, U. 2008. Nollywood, Hives, and Homophobia. The international Resource network in Africa: Outliers, 1:79-82.

Ballard S., \& Morris, M., (1998). Sources of sexuality information for university students. Journal of Sex Education and Therapy, 24(4), 278-287.

Balogun, O. (2006). Jurisprudential Analysis of Yoruba Proverbs. 37 Cambrian L. Rev. 85

Bandura, A. 1977. Social Learning Theory Englewood Cliffs, NJ: Prentice-Hall.

Bewaji, J. (2006). Human Rights: A Philosophical Analysis of Yoruba Conceptions. 37 Cambrian L. Rev. 49.

Brody, S. and Pottera, J. J.(2003). Assessing the role of anal intercourse in the epidemiology of AIDS in Africa. International Journal of STD EAIDS, 14 (7): 431-436. Available online at: www.cirp.ord/library/disease/HIV/brody2003/ (accessed on 10/05/2010).

Calzo, J. P. and Ward, L. M. (2009). Media Exposure and Viewers' Attitude Toward Homosexuality: Evidence for Mainstreaming or Resonance? Journal of Broadcasting and Electronic Media, 53, 2:280299

Davies, M. (7/15/2010) NIGERIA: Homosexuality and pedophilia must be condemned, says primate. Episcopal News Service. online avalable http://www.episcopalchurch.org/81808_123483_ENG_HTM.htm) Last accessed, Ocotber 10, 2010.

Gerbner, G., Gross, L., Morgan, M., Signorelli, N., \& Shanahan, J. (2002). Growing up with television: Cultivation processes. In J. Bryant \& D. Zillman (Eds.), Media Effects: Advances in theory and research (2nd ed., pp. 43-670). Mahwah, NJ: Lawrence Erlbaum Associates.

Haynes, J. (2008). Nollywood: what's in a name?, Africine.org, 17 August 2008. Available at http:/ / www.africine.org/?menu=art\&no=8042 (visited October 10, 2010)

Haynes, J. (2006) Political Critiques in Nigerian video films African Affairs, 105(421): 511-533. 
Horton, D. and Wahl, R. R. (1956). Mass Communication and Para-social Interaction. Psychiatry, 19:215-229.

Lindow, M. (2009). July 21, 2009, How homophobia fuels Africa's AIDS crisis www.Time.com available at http://www.time.com/time/world/article/0,8599,1911757,00.html (last accessed $10 / 22 / 2010)$

Marston, A. S., Woodward, K. and Jones, III, J.P. (2007). Flattening Ontologies of Gloablization: The Nollywood Case. Globalizations, 4, 1: 45-63.

Odinkalu, C., (2000). Why More Africans Don't Use Human Rights Language. Human Rights Dialogue, 2(1) p. 3.

Osofisan, F. (2008). Wounded Eros and Cantillating Cupids: Sensuality and the Future of Nigerian Literature in the Post-Military Era. The international Resource network in Africa: Outliers, 1:64-78

Pew Global Report (2007) available at: http://features.pewforum.org/africa/question.php?q=16 ( last accessed 10/22/2010)

Sabido, M (2004) The Origins of Entertainment-education, in Entertainment-education and Social Change: History, Research, and Practice, eds. A. Sighal, M. Cody, E.M. Rogers, and M. Sabido. Mahwah, NJ: Lawrence Erlbaum Associates.

Simms, L. (2009). Dangerous Lesbians: Same-sex Desire and Domestic Space in Nollywood Videos. Paper presented at International Symposium: Transnational Dimensions of an African Video Film Industry, Johannes Guttenberg University, Mainz, Germany (13-16, May).

Singhal, Arvind. 2007. Popular Media and Social Change: Lessons from Peru, Mexico, and South Africa. Brown Journal of World Affairs, XIII, no. 2:259-270.

Tarchell, P. (5/19/2010). A well-locked closet. The Economist, available online at http:/ / www.economist.com/node/16219402 (Accessed on 10/07/2010, subscription required).

Ukadike, F. N. (1994) Black African Cinema. Berkeley: University of California Press.

Werner, J. (2006) How women are using television to domesticate globalization: a case study on the reception and consumption of telenovelas in Senegal. Visual Anthropology 19: 443-72.

Websites:

http://www.commonplacebook.com/current_events/glbt/nigeriann_advis.shtm

http:/ / www.huffingtonpost.com/2010/02/24/religion-politics-and-afr_n_474258.html (last accessed on $10 / 24 / 2010$ )

\section{Videos}

- $\quad$ Emotional Crack (2003)

- $\quad$ Men in Love (2010)

- $\quad$ Mind Game (2010)

Asian Business Consortium is an independent research house committed to publishing and delivering superior, Peer-reviewed standard research 